\title{
Verification of available glass mechanical properties against recommendation by the draft Eurocode design practice
}

\author{
L. Sable, K. Kalnins \\ Riga Technical University, Institute of Materials and Structures \\ Kipsalas Street 6, LV-1048, Riga, Latvia \\ E-mail: lienesable@gmail.com
}

cross' $^{\text {ref }}$ http://dx.doi.org/10.5755/j01.ct.68.1.18872

Received 17 May 2016; Accepted 10 February 2017

\begin{abstract}
Glass as a structural material has strongly evolved in modern architecture. Wide windows, glass facades and even load-bearing structures make buildings appear transparent and more integrated in the surrounding environment. According to the ongoing effort by the European Committee for Electrotechnical Standardisation, only recently the notice "Eurocode on glass in construction" has been issued. This will make applicable the binding design practice in the EU starting from the next decade. This design practice will include, among others, the required properties of material and products, application fields, respective failure potential and failure consequences, safety and reliability approaches, principles of design, design and calculation rules for primary members, joints, connections and supports. This standard will be binding in all European countries, therefore, until then every member state should adapt these guidelines in order to make safe design practices for glass structures. At present, in Latvia there is no enforced regulation for glass-bearing structural design and a scattered view on the mechanical properties of the available glass applied for load-carrying designs.

In the present verification study, laboratory testings were performed to characterise glass mechanical properties such as stiffness and bending strength of the set of specimens provided by national distributers. For this reason, a series of samples has been tested by a 4-point bending with two different geometrical settings $360 \times 1100 \mathrm{~mm}$ (EN 1228-3) and short beam tests of $50 \times 200 \mathrm{~mm}$. The current research has shown that compared with the Eurocode reference values, these test results show a lower strength of the internally available raw glass panels. The cause should be merged with edge grinding technology and studied in more detail in the further analysis.
\end{abstract}

Key words: glass panels, 4-point bending, tempered glass, annealed glass.

\section{Introduction}

Typical examples of load-bearing glass structures are columns, beams, steps, roofs and floors. The main preferences for glass material are transparency and apparent lightness, but its brittle behaviour without plastic deformations may be considered as negative characteristics. From the mechanical point of view, glass may be considered both as a strong and a stiff material, whereas its Young's modulus ranges within $68 \pm 4 \mathrm{GPa}$ [1], i. e. is similar to the stiffness of aluminium and approximately 1.5 times higher than of reinforced concrete. According to the Guidance for European Structural Design of Glass Components [2], the glass characteristic bending strength is defined for the conventional - annealed - glass $\sigma_{k}$ annealed float glass $=45 \mathrm{MPa}$, heat strengthened glass $\sigma_{k}{ }_{H S G}=$ $70 \mathrm{MPa}$, and for tempered glass $\sigma_{k} T T G=120 \mathrm{MPa}$, also breakage structure and the degree of surface pre- and residual stresses [2]. However, glass is limited to elastic deformations only and its fracture propagation is scattered, which makes it difficult to utilise it as a conventional material in load-bearing structures.

In the current paper, the bending "strength" is referred to as the maximum bending stress. However, it is known that for the bending strengths some scatter could be expected as it largely depends on the geometrical and loading parameters [2]. Along with the increasing popularity of glass in architectural design [3], it is necessary to make an in-depth investigation regarding glass mechanical performance for a reliable design of load-bearing structures [4].

Under loading, glass shows a linear behaviour up to the collapse when it breaks instantly. This is one of the reasons why researchers mostly focus on the fracture properties and try to estimate the ultimate strength for both single and laminate glass plates $[5,6]$.

Some researchers [7] have experimentally investigated the failure strength of glass in bending, using large series of specimens treated in several ways. Also, this author focuses on the Weibull distribution and shows the difference 
between the linear and the bilinear distributions. In a similar research [8], the authors also determine the failure stress for glass panels of the annealed float glass and the fully tempered glass, using different sizes, lying and standing positions.

It has been concluded that a significant effect on the glass stress values is related with the panel edge quality [9] after the cutting process, the grinding and the polishing processes [10]. The edge treatment requires to remove the microstrains and cracks which form during the plate cutting, while decorative processed edges serve as interior design details. Therefore, this process significantly influences the bending strength values by improving or impairing them.

The main types of edge processing [11] are referred to as follows:

1) seamed edge (with blank spots) $-S E$.

2) seamed and dressed-to-size edge (with blank spots) - SDE.

3) ground edge (without blank spots) $-G E$.

4) polished edge $-P E$.

The main difference among the four edge processings is the edge quality after the cutting process. For example, if edges are seamed (Fig. 1, $a$ ), then they are more or less smoothly broken. If the edges are seamed and dressed (Fig. 1, b), then the glass panel is brought to the required dimensions by grinding the surface of its edge. Blank areas and flakes are permissible. In the grounded edge (Fig. 1, c) case, the surface of the glass edge is completely machined. The ground edge has a matt/frosty appearance. Blank areas and flakes are not permissible. The polished edge (Fig. $1, d)$ is a flat ground edge which is further refined by polishing. A certain amount of polishing traces is permissible [12].

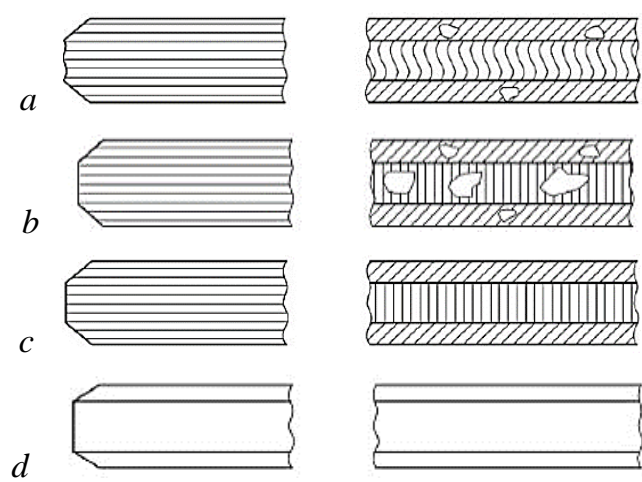

Fig. 1. Glass sample edge treatment: $a$ - seamed edge (with blank spots); $b$ - seamed and dressed to size edge (with blank spots); c - ground edge (without blank spots); $d$-polished edge [2].
Glass mechanical properties may be improved not only with raising the quality of edges or changing the chemical glass content, but also by the alternative technology treatment - tempering. During the tempering process, float glass is heated to approximately $620-675^{\circ} \mathrm{C}$ in a furnace and then cooled rapidly by jets of cold air [13]. After tempering, the glass bending strength increases three times along with the tensile strength being four to six times higher than of annealed glass. The main advantage of tempered glass $(E S G)$ is its ability to handle the impact forces, for example, the human impact to the car's windshield or the facade impact by intrusion.

It should be noted that mainly destructive test methods are available for the evaluation of glass properties. For example, the EN 1288-3:2001 [14] standard for conventional glass is suitable as covering three different test methods:

1. A coaxial double ring test on flat specimens with large surface areas. This test method neglects the edge influence [2].

2. Test specimen are supported at two points (four point bending). The method is only applicable for flat glass, and patterned glass can be tested without restrictions. The test results are the bending strength of the edges [2].

3. The coaxial double ring test on flat specimens with small a test surface area. This test method is only applicable for flat, but not for patterned glass. Compared with the previous test methods, its advantage is the coaxial loading of the glass panel, but the bending strength is by up to $300 \%$ higher [2].

As an alternative to tests by the failure method, one may consider also the non-destructive methods. For example, the method based on the vibration testing of natural frequencies extracting stiffness by the analytical method are provided by ASTM E1876-01 [15]. The main benefits of such a method are not restrictive geometrical properties, and no material is not wasted. Therefore, such approach could be integrated as a quality control step for the further qualification of the loadbearing capacity.

The current research outlines 4-point bending tests for two different glass types (annealed and tempered), with the varied edge processing, thicknesses and sample size. The main task is to estimate the collapse load, the bending strength and to verify the obtained results by the values given by the Eurocodes guidelines. 


\section{Materials and methods}

\section{Experimental investigation}

For the evaluation of the bending strength, sample series from three different glass processing companies in Latvia were collected. Unavailable glass material production lines limit the investigated technological processes to the flat glass cutting edge processing. It should be noted that the material was provided by the same glass producer, while the processing was done individually by each entity following their best practice.

Glass panels have been tested in a 4-point bending test up to breakage according to [14] at the Riga Technical University Institute of Materials and Structures. For bending tests, the INSTRON 8802 and INSTRON E10000 testing machines (Fig. 1 left/right) were utilised, which can perform the tests of tension, compression, bending and fatigue.

The distance between supports was assumed to be constant of $1000 \mathrm{~mm}$ and $180 \mathrm{~mm}$, and the distance between the loading points was set at $200 \mathrm{~mm}$ and $36 \mathrm{~mm}$.

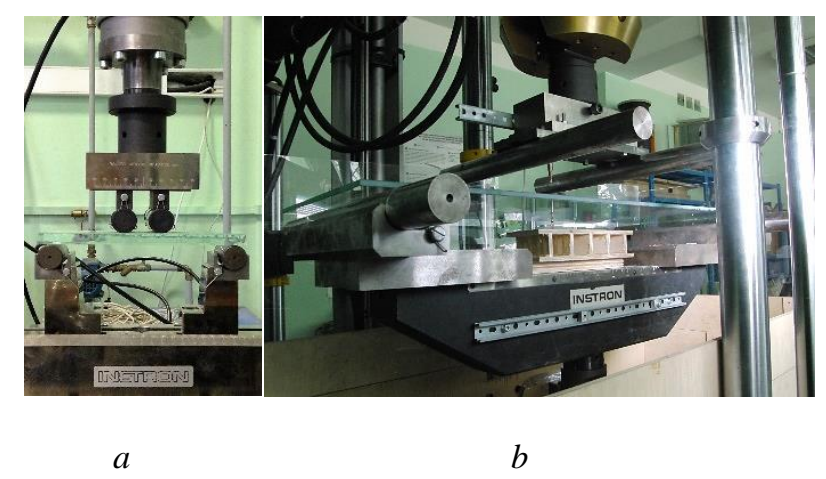

Fig. 2. Glass samples tested in bending: $a-I N S T R O N$ E10000, b-INSTRON 8802.

Glass panel samples have two different geometrical settings: large samples $L_{p}=1100 \mathrm{~mm}$ $\pm 1 \mathrm{~mm}$ long, $b_{p}=360 \mathrm{~mm} \pm 1 \mathrm{~mm}$ wide, and small samples $L_{p s}=200 \mathrm{~mm} \pm 1 \mathrm{~mm}$ long, $b_{p s}=50$ $\mathrm{mm} \pm 1 \mathrm{~mm}$ wide.

Samples were cut from a single glass plate with a nominal thickness of 3/4/5/6/8/10/12 $\mathrm{mm}\left(h_{p}\right)$.

Glass samples were industrially cut on cutting machines and polished with three different grinding lines as required for the best quality glass product. To avoid commercial disputes, the production lines are not named as this would require to disclose the production process best practice which is an industrial secret. For the experimental setup, soda lime float glass sheets were tested without any coating or another chemical processing. Two different types of glass annealed $(A N)$ and tempered $(E S G)$ - were inspected.

In this work, three types of edge-processing technology - seamed and dressed to size edge (with blank spots), ground edge (without blank spots) and polished edge - were experimentally investigated.

\section{Analytical stress analysis}

The maximal bending stress can also be calculated using conventional analytical formulas and the values formerly evaluated by testing. A single glass sheet stress calculation was made according to EN 1288-3:2001 [9]:

$$
\sigma_{b B}=k\left[F_{\max } \frac{3 \cdot\left(L_{s}-L_{b}\right)}{2 \cdot b \cdot h^{2}}+\sigma_{b G}\right] ;
$$

where $F_{\max }-$ maximal load, N; $b$ - the specimen width, $\mathrm{mm} ; h-$ the specimen thickness, $\mathrm{mm} ; L_{s}-$ the distance between the center lines of the supporting rollers, $\mathrm{mm} ; L_{b}-$ the distance between the centre lines of the bending rollers, $\mathrm{mm} ; y$ - the central deflection of a specimen; $k=k_{e}$ - the dimensionless factor as a function of $y / h$ (to determine the stress at the middle of the span $k=1$ ); $\sigma_{b B}$ - the bending strength; $\sigma_{b G}-$ the bending stress imposed by the self-weight of the specimen [14]. The bending stress imposed by the selfweight of the specimen is [14]:

$$
\sigma_{b G}=\frac{3 \cdot \rho \cdot g \cdot L_{s}^{2}}{4 \cdot h} ;
$$

where $\rho$ - density, $\mathrm{kg} / \mathrm{m}^{3} ; g$ - acceleration due to gravity, $\mathrm{m} / \mathrm{s}^{2}$.

\section{Results and discussion}

All test results are summarized in Figures 3 to 9. According to the pre-Eurocode, the reference values are set to characterise the bending strength for annealed glass $\sigma_{k \text { annealed float glass }}=45 \mathrm{MPa}$, while for tempered glass $\sigma_{k T T G}=120 \mathrm{MPa}$. To assess on the market the strength ratios of glass available, several series of glass specimens were ordered from several suppliers, produced by various edge grinding technologies.

A dedicated specimen-marking process for standard annealed glass was established. For example, for the specimen $S D E_{-} 4 \_P 1$, the $S D E$ stands for edge processing, and the number is given for the thickness and followed by the phase number, while all tempered glass specimens are referred to as $E S G$ where the edge processing is always the polished edge. 
During the physical experiments, before placing a sample in the test setup, it had been visually examined whether the annealed glass edges hadn`t been damaged during transportation. After examining and concluding that no visual damage had been found, so it was assumed that the samples could be accepted for testing their mechanical properties.

The initial test phase evaluated the annealed and tempered glass bending strength with seamed and polished edges. The 4-point bending test set-up experimentally verified test samples with the length of $1100 \mathrm{~mm}$ and the width of $360 \mathrm{~mm}$. For each thickness type, a 9-sample test series was conducted. It should be noted that these results did not include $3 \mathrm{~mm}$ thick $P E$ specimens because the currently available technological equipment does not allow to polish glass samples thinner than $3 \mathrm{~mm}$.

Figure 3 shows that the reference $45 \mathrm{MPa}$ strength level was reached only by 8,10 and $12 \mathrm{~mm}$ glass specimens. Furthermore, it can be concluded that the edge processing substantially influences thicker glass plates than thinner ones.

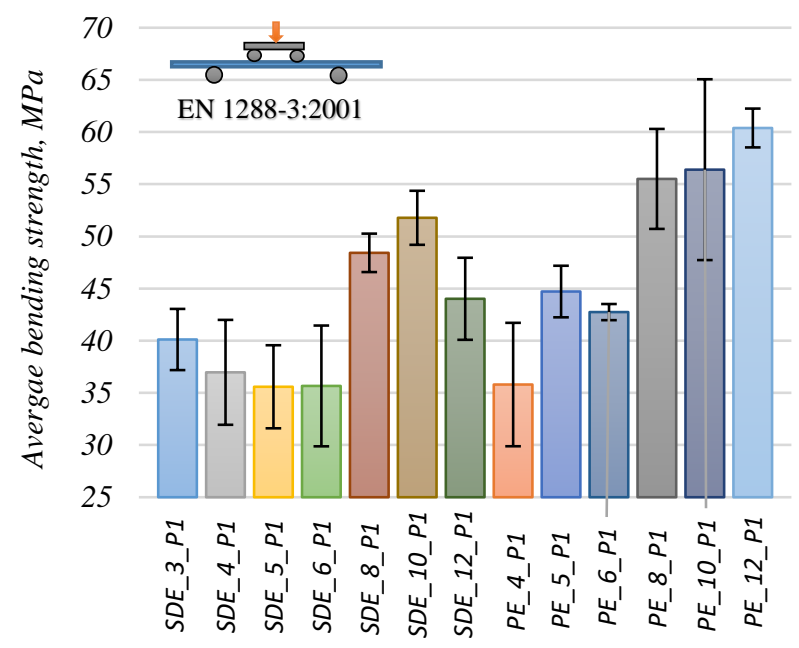

Fig. 3. Histogram of the average bending strength to the first-phase tests and standard deviation for annealed glass with seamed, dressed to size and polished edges.

The initial tempered glass test (Fig. 4) samples were tested according to EN 1288-3:2001. All samples had been prepared in the tempering process at $670-690{ }^{\circ} \mathrm{C}$, and the process took 40 seconds for each $\mathrm{mm}$ of thickness. According to the pre-Eurocode, the tempered glass reference bending strength is $120 \mathrm{MPa}$.

As is shown in Fig. 4, the reference values were achieved only by 10 and $12 \mathrm{~mm}$ thick samples. It should be noted that 4,5 and $6 \mathrm{~mm}$ samples reached the ultimate deflection criteria set without breaking the testing equipment. Therefore, this process may explain why these test values didn't reach $120 \mathrm{MPa}$.

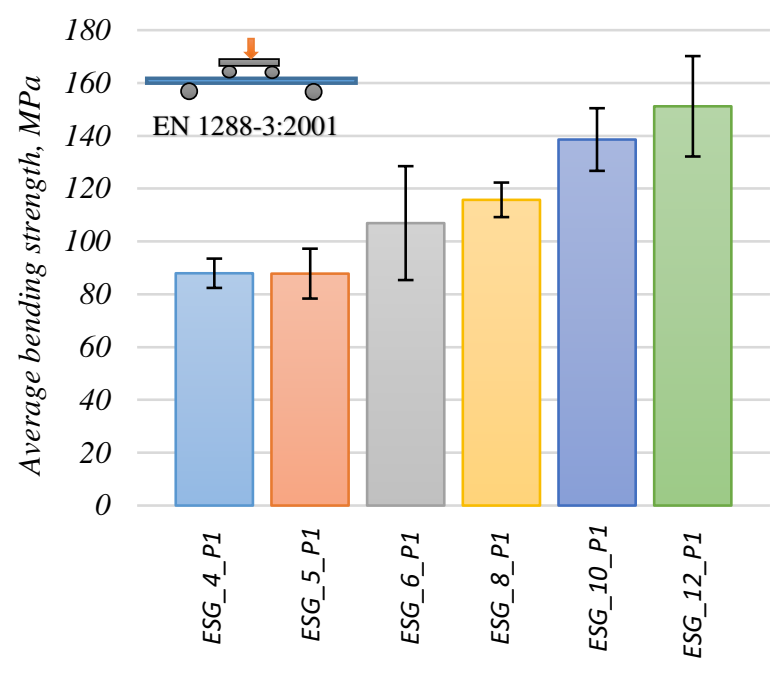

Fig. 4. Histogram of the first-phase testing of the average bending strength and standard deviation for tempered glass.

The second phase was to verify the strength values with small-size samples (length $200 \mathrm{~mm}$ and width $50 \mathrm{~mm}$ ), where for each thickness there were only 5 specimens per series. The samples were provided by the same company as for the initial phase and were tested as strips in a fourpoint bending configuration. In this case the edges were polished, both seamed and dressed. The results show (Fig. 5) that the average failure strength for the specimens was in the range from 15 to $75 \mathrm{MPa}$.

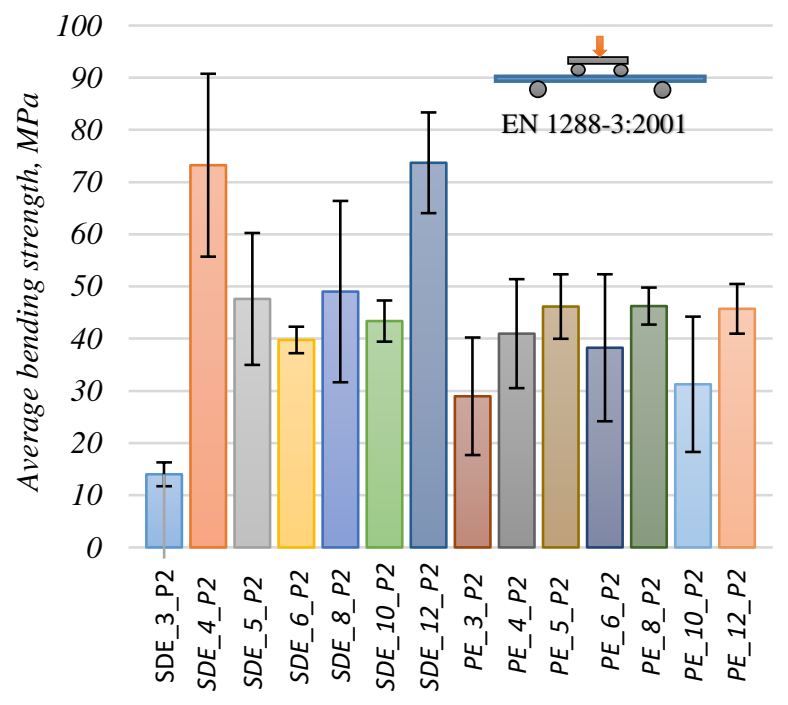

Fig. 5. Histogram of average failure strength and standard deviation for annealed glass with seamed and dressed to size and polished edge. 
Irrespective of the size of the specimen, the glass material must withstand a certain reference strength (45 MPa) under any type of loading. One reason why all small specimens show lower than the reference values may by the fact that the effect of microcracks more affects strength as compared with larger samples.

Each tempering furnace may provide specimens with the maximum and minimum size dimensions that can be produced. Therefore, the sample size $200 \times 500 \mathrm{~mm}$ was too small for the tempering process. Tempering such small specimens may break them under the effect of the heating cooling processes. Therefore, small tempered glasses were not tested in the current study.

In addition, glass specimens from another glass processing company was tested for the verification reasons. The 4, 8, 10 and $12 \mathrm{~mm}$ glass specimens, which are mostly used in architecture, were tested. Samples with both polished and seamed edges were investigated.

Figure 6 shows annealed glass results where glass samples $1100 \times 360 \mathrm{~mm}$ and were experimentally verified with 3 samples for each series. From the statistical analysis point of view, the testing samples are very few; nevertheless, this exercise served the verification purpose only.

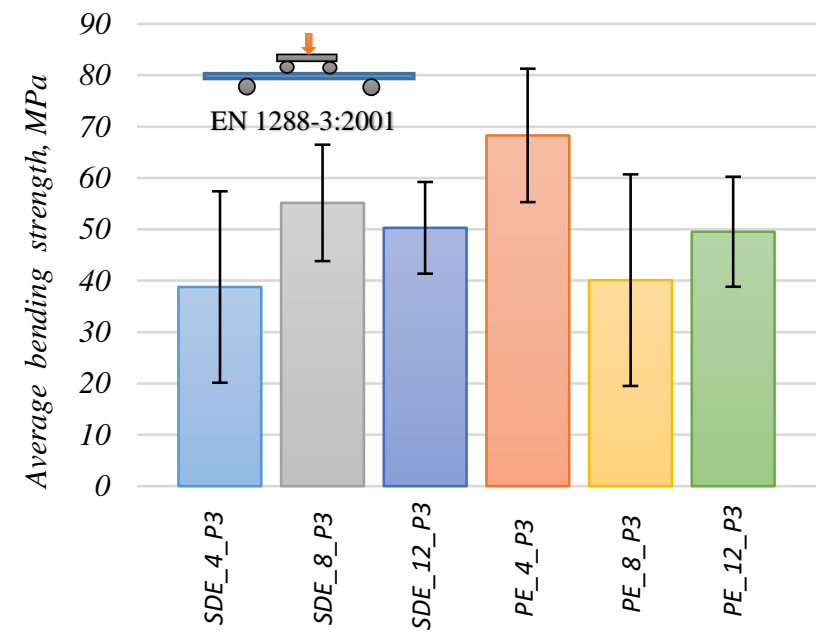

Fig. 6. Histogram of average bending strength for thirdphase tests and standard deviation for annealed glass with the seamed and dressed to size and polished edge.

For the second time, the edge processing was done with other processing machines (Fig. 6). The samples $S D E \_4 \_P 3$ and $P E \_8 \_P 3$ did not reach the reference value of $45 \mathrm{MPa}$. One of the problematic areas is the thin plates processing practice; however, even for $8 \mathrm{~mm}$ glass samples, one out of three samples shows a lower than the reference result; this could explain why a polishededge sample shows a lower average strength.

Tempered glass samples (Fig. 7) are exposed to a more intensive mechanical processing than annealed glass. For example, the edge-polishing processing is mandatory, and only after that the specimen are heated to the required temperature. If after the edge processing some micro-cracks remain, the glass is expected to collapse in the heating process or to show the insufficient bending strength. For this test series, 6 samples with the size $360 \times 1100 \mathrm{~mm}$ were experimentally investigated for each thickness type. Figure 7 summarises that samples $4 \mathrm{~mm}$ thick show a strength below $120 \mathrm{MPa}$, and this could be explained by the previous paragraph discussing the processing and tempering.

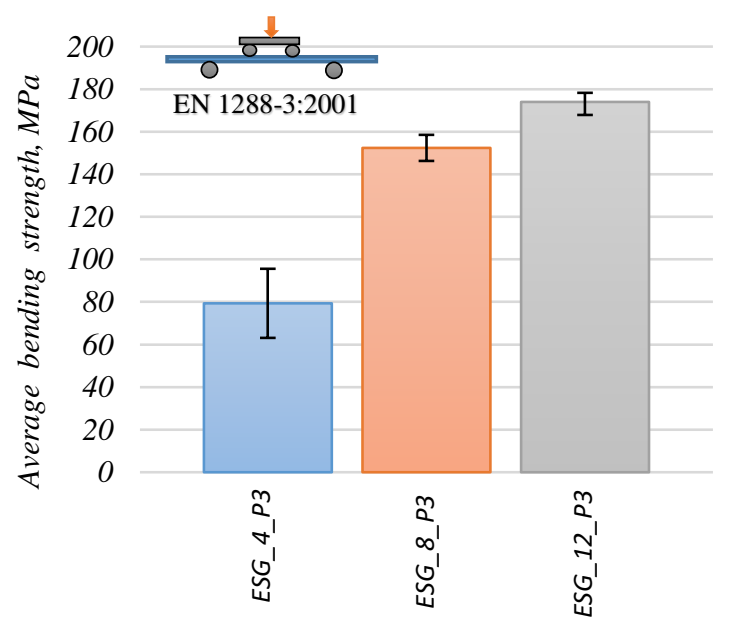

Fig. 7. Histogram of average bending strength for thirdphase tempered glass tests and standard deviation.

For the final phase, all specimens according to the EN 1288-3:2001 were produced with a special focus on the edge grinding $(G E)$ technology. Each test series was composed of 9 tested pieces.

Figures 8 and 9 show the results for annealed and tempered glass samples. Even though the obtained average strength values are higher than the reference ones from pre-Eurocode, the corresponding standard deviation values are not assuring the minimum strength requirements, at least for $10 \mathrm{~mm}$ specimens. 


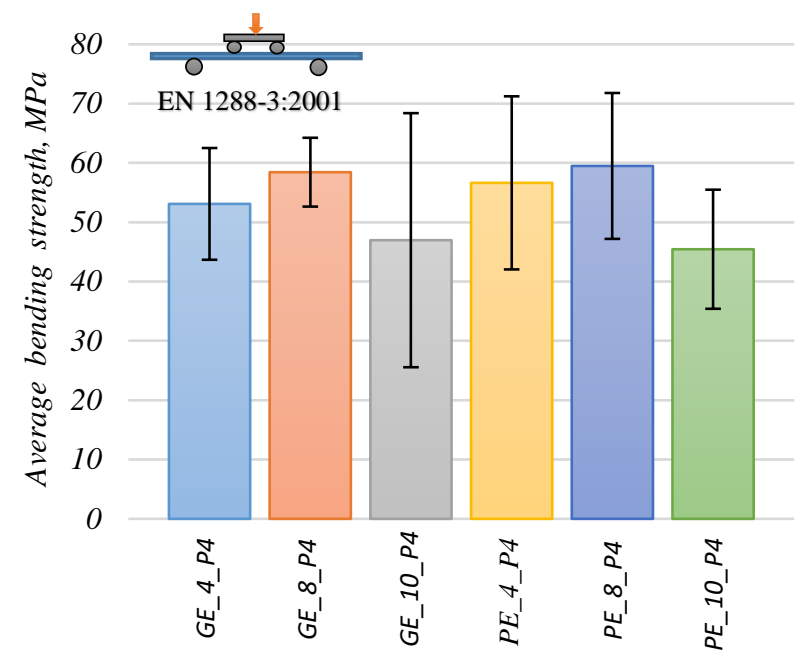

Fig. 8. Histogram of average bending strength for the fourth-phase tests and standard deviation for annealed glass with a grounded and polished edge.

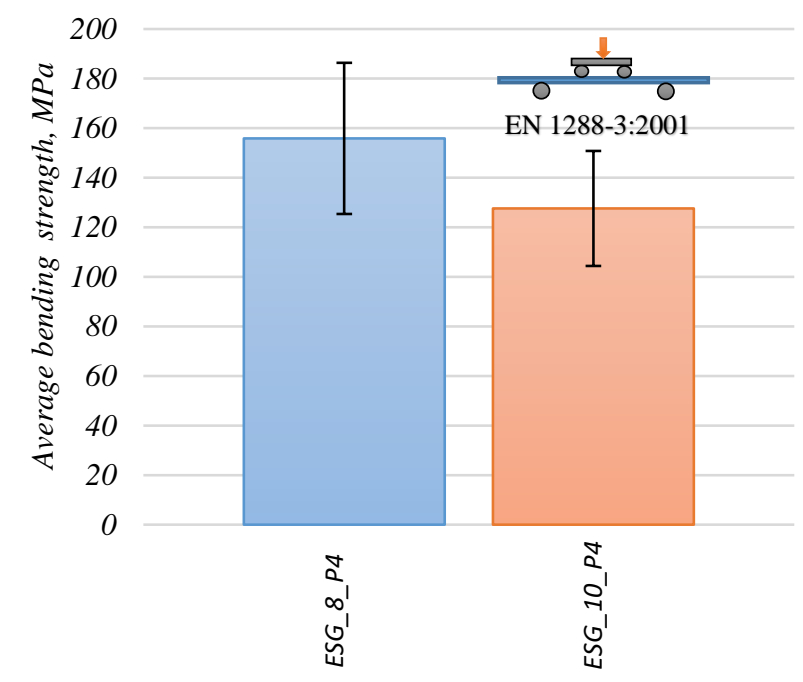

Fig. 9. Histogram of average bending strength for the fourth-phase tests and standard deviation for tempered glass.

\section{Conclusions}

Regardless of the loading type, the thickness, the sample size, the reference bending strength for annealed and tempered glass is set by the preEurocode. The current research draws the conclusion that, compared to the reference values, the obtained average mechanical strength shows lower results for conventional glass panels.

According to the experimental investigation, the average maximal bending strength of annealed float glass reached up to $75 \mathrm{MPa}$, while the lowest strength value was $15 \mathrm{MPa}$, i. e. is three times lower than the reference. Tempered glass shows much more robust results where the maximum bending strength value can reach up to $170 \mathrm{MPa}$ and the minimum $80 \mathrm{MPa}$. Therefore, the lowest bound is nearly $2 / 3$ of the reference value.

The edge-processing aim is to remove microcracks after glass cutting. This process affects the glass material bending strength and varies among suppliers. The experiment results comparing the strength for various edge processes gives lower than the pre-Eurocode-defined ratios, which should be investigated in future for developing the national annex.

\section{References}

1. Šable L., Skukis E., Japinš G., Kalninš K. Inverse technique for the glass stiffness characterization // Proceedings of the 3nd international conference "Optimization and Analysis of Structures, OAS”. Tartu, 2015. P. 110-116.

2. Feldmann M., Kasper R., at. el. Guidance for European structural design of glass components. Luxembourg, Publications Office of the European Union, 2014. 196 p.

3. Noordenne G., Romein T., Veer F. The future of the all transparent pavilion concept // Glass processing days 2005. Tampere, 2005. P. 1-3.

4. Veer F. A., Liebergen M. A. C., Vries S. M. Designing and engineering transparent building components with high residual strength // Glass processing days 1997. Tampere, 1997. P. 13-15.

5. Ramos A., Pelayo F., at el. Analysis of structural glass panels under impact loading using operational modal analysis // Proceedings of 6th International operational modal analysis conference. Lunds, 2015. P. 97-105.

6. Timmel M., Kolling S., Osterrieder P., Du Bois P. A. A finite element model for impact simulation with laminated glass // International Journal of Impact Engineering. 2007. Vol. 34. N 8. P. 14651478. http://dx.doi.org/10.1016/j.ijimpeng.2006.07.008

7. Veer F. A. The strength of glass, a nontransparent value // HERON. 2007. Vol. 52. No. 1/2. P. 87104.

8. Veer F.A., Zuidema J., Bos F.P. The strength and failure of glass in bending // Glass processing days 2005. Tampere, 2005. P. 1-3.

9. Veer F.A., Zuidema J. The strength of glass, effect of edge quality // Glass processing days 2003. Tampere, 2003. P. 106-109.

10. Minko N. I., Nartsev V. M. Factors affecting the strength of the glass (Review) // Middle-East Journal of Scientific Research. 2013. Vol. 18. N 11. P. 1616-1624. http://dx.doi.org/ 10.5829/idosi.mejsr.2013.18.11.70117

11. EN 12150-1:2015. Glass in building - Thermally toughened soda lime silicate safety glass.

12. AGC Interpane. Tolerance Handbook. 2013. 60 p.

13. Wurm J. Glass structures: design and construction of self-supporting skins. Springer, 2007. 255 p. 
14. EN 1288-3:2001. Glass in building Determination of the bending strength of glass Part 3: Test with specimen supported at two points (four point bending). Brussels, 2001.

15. ASTM E1876-01. Standard test method for dynamic Young's modulus, Shear modulus, and Poisson's ratio by impulse excitation of vibration. New York, 2002.
L. Sable, K. Kalnins

\section{STIKLO MECHANINIU SAVYBIU IVERTINIMAS PAGAL EUROKODO PROJEKTO REIKALAVIMUS}

\section{S a n t r a u k a}

Stiklas šiuolaikinèje architektūroje yra plačiai paplitęs struktūrinis elementas. Platūs langai, stiklo fasadai, net laikančiosios konstrukcijos suteikia pastatams skaidrumą ir labiau integruoja juos į aplinką.

Tik Europos elektrotechnikos standartizacijos komiteto pastangomis neseniai išplatintas „Eurocode on glass in construction" pranešimas. Nuo kito dešimtmečio eurokodo projekto reikalavimai taps privalomi visoms ES šalims. Šiame projekte pateikti keliami reikalavimai medžiagų ir gaminių savybèms, taikymo sritys, atitinkami galimi gedimai ir pasekmès, saugos ir patikimumo ivvertinimo metodai, projektavimo principai, pirminių konstrukcinių elementų projektavimo ir skaičiavimo taisyklès, jungtys ir atramos. Šis standartas taps privalomas visose Europos šalyse, todèl iki tol kiekviena valstybè narè, siekdama projektuoti saugias stiklo konstrukcijas, turètų pritaikyti šias gaires. Šiuo metu Latvijoje konkrečių nurodymų, kaip ir kokias projektuoti stiklo konstrukcijas, nèra.

Šiame darbe atlikti laboratoriniai tyrimai, siekiant ịvertinti stiklo mechanines savybes, pavyzdžiui, standumą ir stiprị lenkiant. Bandymams naudoti dviejų skirtingų dydžių stiklo bandiniai. Tyrimai parodè, kad naudotų bandinių stipris, palyginti su eurokodo standarto reikalavimais, yra mažesnis. Tikètina, kad tai yra susiję su stiklo bandinio briaunos šlifavimo technologija. 